\title{
A hyponatraemia klinikai jelentősége
}

\author{
Vígh József dr. ${ }^{1}$ - Ábrahám György dr. ${ }^{2}$ - Kálmán János dr. ${ }^{3}$ \\ Zöllei Magdolna dr. ${ }^{2}$ - Forster Tamás dr. ${ }^{1}$ \\ 1Szegedi Tudományegyetem, Általános Orvostudományi Kar, \\ II. Belgyógyászati Klinika és Kardiológiai Központ, Szeged \\ ${ }^{2}$ Szegedi Tudományegyetem, Általános Orvostudományi Kar, I. Belgyógyászati Klinika, Szeged \\ ${ }^{3}$ Szegedi Tudományegyetem, Általános Orvostudományi Kar, Pszichiátriai Klinika, Szeged
}

\begin{abstract}
A mindennapi klinikai gyakorlatban a hyponatraemia fogalma csaknem 100 éve ismert. Magyarországon az utóbbi 15-20 évben került előtérbe az irodalmi adatok szerint. Klinikai jelentősége fokozatosan növekszik, különös tekintettel súlyos, életveszélyes szövődményeire. A múlt század második felében egyre inkább bebizonyosodott a kórkép korai felismerésének, elkülönítő kórismézésének és hatékony kezelésének jelentősége. Mind a mai napig vannak még vitatott kérdések, eltérő álláspontok, fóként az adekvát kezelést illetően. A betegség főleg az idősebb korosztályokat érinti, azokban is inkább a nőket, akik több különböző betegségben szenvednek egyidejúleg. Minden klinikai szakágban megfigyelhető - multidiszciplináris jelentőségú -, az intrauterin élettôl kezdődôen az elmúlásig végigkíséri a betegeket. Annak ellenére, hogy fatális szövődményeket okozhat, gyakran átsiklunk felette, nem vagy nem időben diagnosztizáljuk, nem vagy nem jól kezeljük a hyponatraemiában szenvedő betegeket. A szerzők 3 típusos hypotoniás hyponatraemiás esetet ismertetnek annak reményében, hogy felhívják a figyelmet ezen igen fontos kórkép menedzselésére.
\end{abstract}

Orv Hetil. 2019; 160(8): 314-319.

Kulcsszavak: hyponatraemia, encephalopathia, ozmotikus demyelinisatiós szindróma, agyödéma

\section{The clinical importance of hyponatremia}

Hyponatremia is a most common disorder of electrolytes encountered in everyday clinical practice. Although many cases are mild and relatively asymptomatic, hyponatremia is nonetheless important clinically because of the potential for substantial morbidity and mortality. Despite the knowledge of hyponatremia since the mid-20th century, this common disorder remains incompletely understood in many basic areas because of its causation by multiple etiologies with differing pathophysiological mechanisms. Up to this time, the optimal treatment strategies have not been well defined. The authors present 3 typical hypotonic hyponatremic patients for colleages in clinical practice for studying, for establishing a common conception for the managing of hyponatremia.

Keywords: hyponatremia, encephalopathy, osmotic demyelinating syndrome, brain oedema

Vígh J, Ábrahám Gy, Kálmán J, Zöllei M, Forster T. [The clinical importance of hyponatremia]. Orv Hetil. 2019; 160(8): 314-319.

(Beérkezett: 2018. október 3.; elfogadva: 2018. november 20.)

\section{Rövidítések}

ACEI = (angiotensin-converting-enzyme inhibitor) angiotenzinkonvertálóenzim-gátló; $\mathrm{ADH}=$ (antidiuretic hormone) antidiuretikus hormon; AIDS = (acquired immundeficency syndrome) szerzett immunhiányos tünetegyüttes; EDTA = (European Dialysis and Transplant Association) Európai Dialízis és Transzplantációs Társaság; ERA = (European Renal Association) Európai Vese Társaság; ERBP = (European Renal Best Practice) Európai Vese Irányelv; ESE = (European Society of Endocrinology) Európai Endokrinológiai Társaság; ESICM
$=($ European Society of Intensive Care Medicine $)$ Európai Intenzív Terápiás Társaság; ITO $=$ (Intensive Therapy Department) Intenzív Terápiás Osztály; NSAID = (non-steroidal antiinflammatory drug) nemszteroid gyulladásgátló; ODS = (osmotic demyelinating syndrome) ozmotikus demyelinisatiós szindróma; $\mathrm{SBO}=($ Emergency Department $)$ Sürgősségi Betegellátó Osztály; SIADH = (syndrome of inappropriate $\mathrm{ADH})$ nem megfelelő $\mathrm{ADH}$-termelési tünetegyüttes; SSRI = (selective serotonin reuptake inhibitor) szelektív szerotoninvisszavétel-gátló; SZTE = Szegedi Tudományegyetem 
A mindennapi klinikai gyakorlatban a hyponatraemia a leggyakoribb só- és vízháztartási rendellenesség. A sürgősségi indokkal hospitalizált betegek közötti előfordulása $15-30 \%$-ra tehető. $\mathrm{Az}$ arány a szívelégtelenségben szenvedők körében $27-50 \%$, a geriátriai betegségben szenvedőknél 30-53\%, míg a iatrogén ártalmat elszenvedők között már 40-75\% is lehet. Az utóbbi években megnőtt a posztoperatív és a gyermekgyógyászati közlemények száma is.

Az első hyponatraemiás eseteket már a múlt század 20-as éveiben leírták. 1936-ban közölték az első halálos kimenetelü posztoperatív esetet. Schwartz és Bartter 1957-ben elsőként számolt be az inadekvát ADH-szindrómáról (SIADH), melyet később róluk neveztek el. Az 1970-es évektől ismert az ozmotikus demyelinisatiós szindróma (ODS). A vazopresszinreceptor-antagonistákat 2005-től kezdve alkalmazzák a terápiában. 2005 és 2014 között az Egyesült Államokban 6 egyetemi klinikán, Európában 17 egyetemi klinikán, valamint 3 európai szakértői társaságban - Európai Intenzív Terápiás Társaság (ESICM), Európai Vese Társaság \& Európai Dialízis és Transzplantációs Társaság (ERA-EDTA), Európai Endokrinológiai Társaság (ESE) - foglalkoztak a kutatók részletesen és ismételten a hyponatraemia klinikai jelentőségével [1-3].

A szerzők 3 típusos hypotoniás hyponatraemiás esetet mutatnak be az olvasónak, ismételten hangsúlyozva a kórkép jelentőségét a mindennapi sikeres gyógyítómunka érdekében.

\section{A hypotoniás hyponatraemia 3 típusos esete}

\section{Hypovolaemiás hypotoniás hyponatraemia (SZTE, Pszichiátriai Klinika)}

Egy 70 éves nőbeteg tartós, súlyos depresszió miatt különböző antidepresszánsokat (benzodiazepinek, paroxetin, szertralin), hypertonia miatt ramiprilt, tiazidot, $\mathrm{cu}^{-}$ korbetegség miatt metformint szedett hosszú időn keresztül. Egy héten át tartó hányinger, hányás, hasi panaszok után a szérumnátrium $(\mathrm{seNa}) 116 \mathrm{mmol} / 1 \mathrm{szint}-$ re csökkent. A szérumkreatinin $135 \mathrm{mmol} / 1$, míg a szérum-karbamid-nitrogén 15,5 mmol/1 szintre emelkedett. Teljesen legyengült, szédült, kiszáradt, ataxiássá vált. Fizikális vizsgálat alkalmával az exsiccosis jelei - beesett szemek, száraz nyelv, csökkent turgorú bőr - szembetünőek voltak. Az antidepresszánsok elhagyásának, valamint 0,9\%-os NaCl- és Ringer-laktát infúzióknak (2000$3000 \mathrm{ml} /$ nap dózisban) a hatására a seNa-szint 72 óra alatt eleinte 120-125, majd 130-135 mmol/1 szintre emelkedett. A szérumozmolaritás ezzel arányosan a kezdeti $242 \mathrm{mOsm} / \mathrm{kg}$ szintről fokozatosan 263-275-284 $\mathrm{mOsm} / \mathrm{kg}$ szintre emelkedett, az extrarenalis azotaemia megszünt. A folyadék- és elektrolitpótlás hatására a beteg panaszai csökkentek, majd elmúltak. Fizikális állapo- ta rendeződött. Pszichiátriai kezelése folytatódott, de a továbbiakban a tiazidokat és a fenti antidepresszánsokat elhagytuk, mivel egyértelműen patogenetikai tényezőként szerepeltek a hyponatraemia kiváltásában.

\section{Euvolaemiás hypotoniás hyponatraemia- SIADH (SZTE, I. Belgyógyászati Klinika)}

A 60 éves nőbeteget hypertensiv krízis, epilepszia, hyponatraemia miatt SBO-ra szállították. Hyponatraemiás epileptiform rosszullétei már 2 éve ismertek voltak, ismétlődtek. Kórelőzményében ezenkívül depresszió, köszvény, polyarthrosis szerepelt. Tartósan szedett antidepresszánst (venlafaxin). Interkurrens gastroenterocolitis miatt az Infektológiai Klinikára került. Itt folyadék- és elektrolitterápiában fiziológiás $0,9 \%$-os $\mathrm{NaCl}$ - és Ringer-laktát infúziókban részesült káliumpótlással, levofloxacin és probiotikum adásával. Egyre fokozódó hyponatraemia (108 mmol/l) következtében zavartság, soporosus-comatosus állapot lépett fel, mely miatt az Intenzív Terápiás Osztályra került. Az endokrinológiai konzílium SIADH-t állapított meg, kezdődő renalis insufficientia tüneteivel. A hyponatraemia kiváltásában az antidepresszáns és az interkurrens fertőzés vezető szerepet játszott. Az antidepresszánsterápia azonnali leállítása mellett, szigorú monitorozással 3\%-os hypertoniás $\mathrm{NaCl}$-infúzió adását kezdték el. Az induló 108-110 mmol/l szintü hyponatraemia fokozatosan 115-120 mmol/l-re emelkedett, majd a harmadik napon normalizálódott 135-138 mmol/1 szinten. A szérumozmolaritás eredményei a seNa-szintet követték: 210-241-264$288 \mathrm{mOsm} / \mathrm{kg}$ mértéken. A kezdetben észlelt extrarenalis azotaemia megszünt. Ennek ellenére tudati állapota nem javult, vigil kóma alakult ki, mely tartósan fennmaradt. A neurológiai és endokrinológiai konzílium az ODS lehetőségét kizárta. A továbbiakban a SZTE I. Belgyógyászati Klinikájának Geriátriai Osztályán 10 hétig állt kezelés alatt, mely időszakban a seNa értékei 134-142 mmol/1 között alakultak. Adekvát belorvosi kezelésben és gondos ápolásban részesült, melynek ellenére végül hypertensiv crisis, keringés és légzésbénulás tünetei között exitált.

A boncolási jegyzőkönyv szerint a halál beálltát agyödéma, a kisagy beékelődése következtében kialakult centrálislégzés- és keringésleállás okozta. A szövettani feldolgozás demyelinisatiós elváltozásokat nem talált.

\section{Hypervolaemiás hypotoniás hyponatraemia (SZTE, II. Belgyógyászati Klinika, Általános Kardiológia)}

A 85 éves nőbeteg perzisztáló pitvarfibrilláció miatt került felvételre elektromos cardioversio céljából. Felvétele elött perindoprilt, tiazidot, amlodipint, furoszemidet, káliumot, nitrátokat, kumarint szedett. A kezelés ellenére kis és nagy vérköri vizenyők, dyspnoe, adynamia, ata- 
xia, bradyarrhythmia, szívelégtelenség alakult ki. Felvételekor seNa-szintje $115 \mathrm{mmol} / 1$, a szérumkreatinin 166 mmol/1, a szérum-karbamid-nitrogén 18,6 mmol/1 volt. Folyadékmegszorítás, adekvát diuretikus kezelés (napi $2 \times 40-80 \mathrm{mg}$ furoszemid iv.), káliumpótlás, cardialis támogatás következtében a seNa-szint 72 órán belül 121-130-134-140 mmol/l-re emelkedett. A szérumozmolaritás követte a seNa-szintet, a kezdeti 249 $\mathrm{mOsm} / \mathrm{kg}$ után 263-275-284 mOsm/kg szinten normalizálódott, a vesefunkciós zavar megszünt. A kezelés 4. napján sikeres DC-cardioversio történt, a sinusrhythmus helyreállt szövődmény nélkül. Hétnapos kezelés után cardialisan kompenzált állapotban, normális sinusrhythmusban, panaszmentesen otthonába távozott. A súlyos hyponatraemiát a szívelégtelenség, a tiazid diuretikum és az ACEI-terápia okozta.

Az esetenként súlyos, gyakran életveszélyes klinikai állapot megértéséhez szükséges a kórélettani alapok pontos ismerete ahhoz, hogy a terápia sikeres legyen.

\section{A hyponatraemia kórélettani következményei}

- Az alcsony seNa-szint megbontja az extracelluláris és intracelluláris tér ozmotikus egyensúlyát, aminek következtében szabad víz áramlik a sejtekbe, sejtduzzadást okozva. A sejtduzzadás akut fokozódása agyödémához, majd a nyúltagy beékelődéséhez, keringés- és légzésbénuláshoz vezethet.

- Ezzel ellentétes biokémiai folyamat következik be akkor, amikor az alacsony seNa-szint gyors korrekciója folyamán - „overcorrection” - a sejtekből szabad víz áramlik vissza az extracelluláris térbe, ami neurondegenerációt, ozmotikus demyelinisatiós szindrómát (ODS) okoz, az előzőekben leírt végkimenettel.

Ezen kétirányú - valójában igen bonyolult - kórélettani folyamatok kezelése, szabályozása adja meg a hyponatraemia multidiszciplináris jelentőségét.

A hyponatraemia felosztása a biokémiai súlyosság alapján

- Enyhe mértékű: a seNa 130-134 mmol/1 között.

- Közepes mértékú: a seNa 125-129 mmol/1 között.

- Súlyos mértékü: a seNa 120-124 mmol/1 között.

- Igen súlyos mértékü: a seNa $120 \mathrm{mmol} / \mathrm{l}$ alatt van.

A hyponatraemia felosztása kialakulásának időtartama alapján

- Akut hyponatraemia: 48 órán belül alakul ki.

- Krónikus hyponatraemia: 48 órán túl alakul ki.

A hyponatraemia felosztása a tünetek súlyossága szerint

- Enyhe esetben tünetmentes lehet.

- Középsúlyos esetben: fejfájás, hányinger, ataxia, zavartság, esések, törések.

- Súlyos tünetek: hányás, görcsök, aluszékonyság, keringési és légzési elégtelenség, kóma.

\section{A hyponatraemia felosztása a szérum ozmolaritása alapján, differenciáldiagnosztika (1. táblázat)}

\section{Isotoniás hyponatraemia (280-295 $\mathrm{mOsm} / \mathrm{kg})$}

Hyperlipidaemiában és hyperproteinaemiában tapasztalható. A plazmaozmolaritás mértékét a zsírok és a fehérjék nem befolyásolják. Megfelelő laboratóriumi háttér szükséges. A szérum- és vizeletozmolaritás meghatározása azonos időpontokban történjen.

\section{Hypertoniás hyponatraemia (>295 mOsm/kg)}

A leggyakrabban hyperglykaemiában észleljük. Szabad víz áramlik a sejtekből az extracelluláris térbe, hemodilúció folytán hyponatraemia alakul ki.

Az isotoniás és hypertoniás hyponatraemia nem valódi hyponatraemia. Az alapbetegség hatékony kezelésére normonatraemia jön létre.

A szérumozmolaritás az alábbi képlet alapján számítható ki:

Ozmolaritás $=2 \times \mathrm{Na}(\mathrm{mmol} / \mathrm{l})+2 \times \mathrm{K}(\mathrm{mmol} / \mathrm{l})+$ glükóz $(\mathrm{mmol} / \mathrm{l})+B U N(\mathrm{mmol} / \mathrm{l})$

(BUN = karbamid-nitrogén)

\section{Hypotoniás hyponatraemia (<280 $\mathrm{mOsm} / \mathrm{kg})$}

Valódi hyponatraemia.

\section{A hyponatraemia felosztása a volumenstatus szerint (2. táblázat)}

\section{Hypovolaemiás hypotoniás byponatraemia}

A csökkent extracelluláris folyadéktérfogattal járó hyponatraemia renalis vagy extrarenalis folyadékvesztéskor lép fel. A szervezet összvíz- és -nátriumtartalma csökken. Az intravascularis térfogat fenntartása érdekében az $\mathrm{ADH}$

1. táblázat A hyponatraemia felosztása a szérum ozmolaritása alapján, differenciáldiagnosztika

\begin{tabular}{|c|c|c|}
\hline $\begin{array}{l}\text { Normális ozmolaritás } \\
(280-295 \mathrm{mOsm} / \mathrm{kg})\end{array}$ & $\begin{array}{l}\text { Alacsony ozmolaritás } \\
(<280 \mathrm{mOsm} / \mathrm{kg})\end{array}$ & $\begin{array}{l}\text { Magas ozmolaritás } \\
(>295 \mathrm{mOsm} / \mathrm{kg})\end{array}$ \\
\hline $\begin{array}{l}\text { Isotoniás hyponatrae- } \\
\text { mia } \\
\text { 1. Hyperproteinae- } \\
\text { mia } \\
2 \text { Hyperlipidaemia } \\
\text { (kilomikronok, } \\
\text { trigliceridek) }\end{array}$ & $\begin{array}{l}\text { Hypotoniás } \\
\text { byponatraemia } \\
\text { Valódi hyponatrae- } \\
\text { mia }\end{array}$ & $\begin{array}{l}\text { Hypertoniás } \\
\text { byponatraemia } \\
\text { 1. Hyperglykaemia } \\
\text { 2. Mannitol, } \\
\text { szorbitol, glicerin, } \\
\text { maltóz használata } \\
\text { 3. Röntgenkontraszt- } \\
\text { anvagok }\end{array}$ \\
\hline
\end{tabular}




\begin{tabular}{|c|c|c|c|}
\hline Hypovolaemiás & & Normovolaemiás & Hypervolaemiás \\
\hline $\begin{array}{l}\text { Vizelet }_{\mathrm{Na}+}<10 \text { maeq } / 1 \\
\text { Extrarenalis sóvesztés: } \\
\text { 1. Dehidráció } \\
\text { 2. Hasmenés } \\
\text { 3. Hányás }\end{array}$ & $\begin{array}{l}\text { Vizelet }_{\mathrm{Na}}>20 \text { maeq } / 1 \\
\text { Renalis sóvesztés: } \\
\text { 1. Diuretikumok } \\
\text { 2. ACE-inhibitorok } \\
\text { 3. Nephropathiák } \\
\text { 4. Mineralokortikoidhiány } \\
\text { 5. Cerebralis nátriumvesztó } \\
\text { szindróma (CWS) }\end{array}$ & $\begin{array}{l}\text { 1. SIADH (inadekvát ADH- } \\
\text { szindróma), okai a 3. táblázat- } \\
\text { ban láthatók }\end{array}$ & $\begin{array}{l}\text { Ödémaképződés: } \\
\text { 1. Pangásos szívelégtelenség } \\
\text { 2. Májbetegség } \\
\text { 3. Nephrosisszindróma (ritka) } \\
\text { 4. Súlyos veseelégtelenség }\end{array}$ \\
\hline
\end{tabular}

ACE = angiotenzinkonvertáló enzim; ADH = antidiuretikus hormon; SIADH = nem megfelelő antidiuretikus hormontermelési tünetegyüttes

szekréciója növekszik, így szabad vizet tart vissza a vese. A só- és vízveszteség csak vízzel pótlódik.

- Kezelése: 0,9\%-os NaCl-infúzió, Ringer-infúzió, az alapbetegség kezelése.

\section{Hypervolaemiás hypotoniás hyponatraemia}

A megnövekedett extracelluláris folyadéktérfogattal járó hyponatraemia ödémával fellépő kórképekben jelentkezik, például pangásos szívelégtelenség, májcirrhosis, nephrosisszindróma, veseelégtelenség.

- Kezelése: folyadékmegvonás, kacsdiuretikumok, az alapbetegség kezelése. $125 \mathrm{mmol} / \mathrm{l}$ seNa-szint alatt megfontolandó kis mennyiségű 3\%-os NaCl-infúzió adása furoszemiddel a vízdiurézis növelése és a seNa emelése céljából. A vazopresszinantagonisták alkalmazása még vitatott, nagy körültekintést igényel (dózis, idő, mellékhatások). Az európai társaságok - (ERBP, ESICM, ESE, ERA, EDTA) - nem javasolják alkalmazásukat. Ennek ellenére már Európában is több or- szágban - Egyesült Királyság, Spanyolország, Svédország - elfogadott a szakszerűen monitorozott vazopresszinantagonisták alkalmazása. Magyarországon a legújabb, 2017. évi szakmai irányelv szerint a tolvaptánkezelés egyénre szabottan, gondos mérlegelést követően alkalmazható [4-6].

\section{Euvolaemiás hypotoniás hyponatraemia}

Inadekvát $\mathrm{ADH}$-szindróma $=\mathrm{SIADH}($ Schwartz-Bartter-szindróma)

- Jellemző: hyponatraemia, fokozott ADH-szekréció, csökkent ozmolaritás: $280 \mathrm{mOsm} / \mathrm{kg}$ alatt. Vizelet$\mathrm{Na}: 30 \mathrm{mmol} / \mathrm{l}$ felett, vizeletozmolaritás: $100 \mathrm{mOsm} /$ $\mathrm{kg}$ felett.

A SIADH leggyakoribb okait a 3. táblázatban foglaltuk össze.

- A SIADH kezelése:

1) Folyadékmegszorítás: napi $1 / 2-1$ liter maximális bevitel.

3. táblázat $\mid$ A SIADH leggyakoribb okai

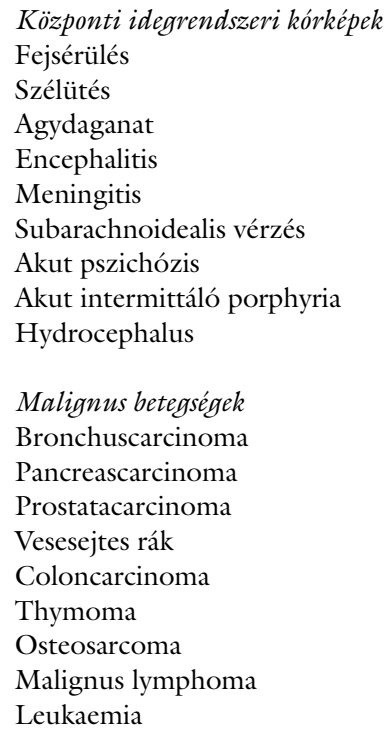

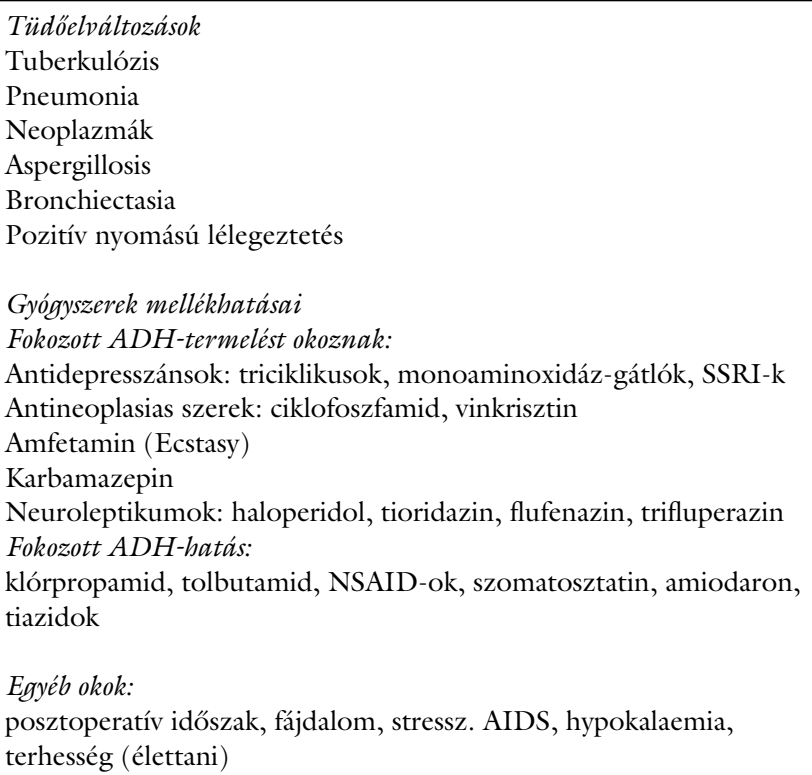

$\mathrm{ADH}=$ antidiuretikus hormon; AIDS = szerzett immunhiányos tünetegyüttes; NSAID = nemszteroid gyulladásgátló; SIADH = nem megfelelő antidiuretikus hormontermelési tünetegyüttes; SSRI = szelektív szerotoninvisszavétel-gátló 
2) Kis dózisú kacsdiuretikum kombinálása orális $\mathrm{NaCl}$ bevitellel.

3) A gyógyszermellékhatások kivédése.

4) Az alapbetegség/ek kezelése.

5) A vazopresszinreceptor-gátlók alkalmazása megfontolandó.

6) Lítium és demeklociklin adása nem javasolt.

7) Isotoniás $\mathrm{NaCl-oldat} \mathrm{infúziójával} \mathrm{SIADH-ban} \mathrm{a} \mathrm{se-}$ Na-szint nem emelhető [7-9].

\section{A súlyos hyponatraemia kezelése}

1) Azonnali kezelés indokolt, függetlenül az akut vagy krónikus előzménytől.

2) $150 \mathrm{ml} / 50 \mathrm{~kg}$ testsúly $\mathrm{kg}$ 3\%-os NaCl-infúzió beadása 20 perc alatt, seNa-szint ellenőrzése 20 perc után.

3 ) Ismételten $150 \mathrm{ml} / 50 \mathrm{~kg}$ 3\%-os $\mathrm{NaCl}$-infúzió beadása 20 perc alatt. Ismételt seNa-szint-ellenőrzés.

4) Indokolt az infúzió ismétlése mindaddig, amíg a seNa-koncentráció emelkedése az $5 \mathrm{mmol} / \mathrm{l}$ célértéket eléri. A seNa-szint emelkedése ne legyen $1 / 2-1$ mmol/1/óra felett! Ennek biztosítására szakértői kezelés és kvalifikált laboratóriumi körülmények szükségesek a nap 24 órájában.

$5)$ További kezelés: az 5 mmol/l seNa-szint-emelkedési célérték elérése után a lehető legkisebb volumenú fiziológiás $\mathrm{NaCl}$-cseppinfúzió folytatandó az oki terápia megkezdéséig, illetve a $125-130 \mathrm{mmol} / 1$ seNa-céltartomány eléréséig.

6) A seNa-szint ellenőrzése 2-3 óránként, a céltartomány elérése után 6-12 óránként, majd naponta indokolt.

7) Ajánlott a specifikus oki kezelés megkezdése a nátriumszint stabilizációja érdekében, lehetőség szerint minél előbb.

8) Az első 24 órában összesen $10 \mathrm{mmol} / \mathrm{l}$, azt követően pedig naponként további $8 \mathrm{mmol} / \mathrm{l}$ a seNa-szint emelkedésének felső határa, amíg annak koncentrációja eléri a $130 \mathrm{mmol} / \mathrm{l}$ célértéket.

A túlzottan gyors seNa-szint-emelkedés az ODS veszélyét jelenti. Ennek megelőzése rendkívül fontos feladat [10-12].

\section{Az ODS kezelése}

1) Azonnali beavatkozás indokolt a seNa-szint csökkentésére, ha az az első 24 órában több, mint $10 \mathrm{mmol} /$ 1-rel, vagy minden azt követő 24 órában több, mint 8 mmol/l-rel emelkedett.

2) Javasolt a folyamatban lévő aktív terápia felfüggesztése.

3) Szakértővel való konzultáció javasolt, hogy szükséges-e 1 óra alatta $10 \mathrm{ml} /$ testsúlykg dózisban elektrolitmentes infúzió (például glükóz) indítása a vizeletmennyiség és a folyadékháztartás szoros monitorozása mellett.
4) A vizeletmennyiség hirtelen, $100 \mathrm{ml} / \mathrm{h}$ feletti növekedése előre jelzi a seNa-koncentráció túl gyors emelkedését. Ebben az esetben tanácsos a seNa-koncentrációt 2 óránként mérni addig, amíg stabilizálódik.

5 ) Szakértővel ajánlott konzultálni, indokolt-e iv. 1-2 mikrogramm dezmopresszin- (Minirin, Octostim) terápia, figyelembe véve, hogy az nem adható gyakrabban, mint 8 óránként [13-15].

\section{Következtetések}

- A hyponatraemia életveszélyes szövődményekkel járhat.

- Vegyük nagyon komolyan a menedzselését.

- Fontos a korai felismerés.

- Speciális kezelés kell szakértő bevonásával.

- Folyamatos monitorozás szükséges, megfelelő helyen.

- Fontos az alapbetegség hatékony kezelése.

- Minden súlyos esetben részletes kivizsgálás szükséges.

- Súlyos esetben (seNa 120 mmol/l alatt!) ITO konzílium/kezelés indokolt.

- Mindenképpen kivédendő az ozmotikus encephalopathia.

- Csak szakképzett és a kórképben jártas orvos vállalja a súlyos hyponatraemia kezelését [16-19].

Anyagi támogatás: A közlemény megírása anyagi támogatásban nem részesült.

Szerzői munkamegosztás: A kézirat elkészítésében a szerzők közösen vettek részt. A cikk végleges változatát valamennyi szerző elolvasta és jóváhagyta.

Érdekeltségek: A szerzőknek nincsenek érdekeltségeik.

\section{Köszönetnyilvánítás}

A szerzők ezúton is köszönetet mondanak Kiss Zoltán dr. kardiológus föorvosnak hasznos tanácsaiért.

\section{Irodalom}

[1] Spasovski G, Vanholder R, Allolio B, et al. Clinical practice guideline on diagnosis and treatment of hyponatraemia. Nephrol Dial Transplant. 2014; 29(Suppl 2): il-i39.

[2] Verbalis JG, Goldsmith SR, Greenberg A, et al. Diagnosis, evaluation and treatment of hyponatremia: expert panel recommendations. Am J Med. 2013; 126(Suppl 1): S1-S42.

[3] Health professional guiding on diagnosis and therapy of hyponatremia. [Egészségügyi szakmai irányelv. - A hyponatraemia diagnosztikájáról és kezeléséről.] Emberi Erőforrások Minisztériuma, Egészségügyért Felelős Államtitkárság. Egészségügyi Közlöny 2017; 66(2): 455-472. Available from: https://kollegium.aeek. hu [accessed: November 20, 2018]. [Hungarian]

[4] Sulyok E. A few clinical aspects of sodium homeostasis disorders. [A nátriumháztartás zavarainak néhány klinikai vonatkozása.] Orv Hetil. 2013; 154: 1488-1497. [Hungarian]

[5] Schwartz WB, Bennett W, Curelop S, et al. A syndrome of renal sodium loss and hyponatremia probably resulting from inappro- 
priate secretion of antidiuretic hormone. Am J Med. 1957; 23: 529-542.

[6] Sterns RH, Emmett M, Forman JP, et al. Osmotic demyelination syndrome (OSD) and overly rapid correction of hyponatremia. UpToDate, Last updated: July 20, 2018 [accessed: November 20, 2018].

[7] Runkle I, Villabona C, Navarro A, et al. Treatment of hyponatremia induced by the syndrome of inappropriate antidiuretic hormone secretion: a multidisciplinary Spanish algorithm. Nefrologia 2014; 34: 439-450.

[8] Radó P. Water intoxication during carbamazepine treatment. Br Med J. 1973; 3(5878): 479.

[9] Radó J, Csányi P. Hyponatremia caused diuretic. [Diureticum okozta vízintoxicatio hyponatraemia.] Orv Hetil. 1989; 130: 25-26. [Hungarian]

[10] Haris Á, Radó J. Disorders of the water and fluid balance. [A vízés elektrolit-háztartás zavarai.] Medicina Könyvkiadó, Budapest, 2008. [Hungarian]

[11] Haris Á. Differential diagnosis of the electrolyte abnormalities. Hyponatremia. [Elektrolit-rendellenességek differenciáldiagnosztikája. Hyponatraemia.] Hyperton Nephrol. 2002; 6: 121-124. [Hungarian]

[12] Lewis JL 3rd. Hyponatremia. Endocrine and metabolic disorders. MSD Manual, Last full review/revision March 2018 [accessed: June 15, 2018].
[13] Narins RG, Jones ER, Stom MC, et al. Diagnostic strategies in disorders of fluid, electrolyte and acid-base homeostasis. Am J Med. 1982; 72: 496-520.

[14] Cho KC, Fukagawa M, Kurokawa K, et al. Fluid and electrolyte disorders. McGraw-Hill, New York, NY, 2007.

[15] Nyirkos P. Hyponatremia. (Hyponatrémia.) Melánia Kiadó, Budapest, 2005. [Hungarian]

[16] Avila M. The Clinical Practice Guideline on diagnosis and treatment of hyponatraemia: a response from Otsuka Pharmaceutical Europe Ltd. Eur J Endocrinol. 2014; 171: L1-L3.

[17] Simon EE. Hyponatremia treatment and management. Medscape, Updated: January 6, 2018 [accessed: June 15, 2018].

[18] Laczi F. Etiology, diagnostics and therapy of hyponatremias. [A hyponatraemiás állapotok etiológiája, diagnózisa és terápiája.] Orv Hetil. 2008; 149: 1347-1354. [Hungarian]

[19] Tzamaloukas AH, Shapiro JI, Raj DS, et al. Management of severe hyponatremia: infusion of hypertonic saline and desmopressin or infusion of vasopressin inhibitors? Am J Med Sci. 2014; 348: 432-439.

(Vígh József dr., Szeged, Semmelweis u. 8., 6725 e-mail: drvijo331@gmail.com)

\section{"Praetermissa frustra revocantur." (Plinius) (Azt, amit elmulasztottunk, hiába hívjuk vissza.)}

A cikk a Creative Commons Attribution 4.0 International License (https://creativecommons.org/licenses/by/4.0/) feltételei szerint publikált Open Access közlemény, melynek szellemében a cikk bármilyen médiumban szabadon felhasználható, megosztható és újraközölhetö, feltéve, hogy az eredeti szerzỏ és a közlés helye, illetve a CC License linkje és az esetlegesen végrehajtott módositások feltüntetésre kerülnek. (SID_1) 